\title{
Local Government Implicit Debt Under China's Public Private Partnerships: Scope, Formation and Governance
}

\author{
Lizhen Li, Xiumei An \\ The School of Public Finance and Taxation, Central University of Finance and Economics, Beijing, P. R. China \\ Email address: \\ 351891138@qq.com (Lizhen Li), cufeaxm@163.com (Xiumei An) \\ To cite this article: \\ Lizhen Li, Xiumei An. Local Government Implicit Debt Under China's Public Private Partnerships: Scope, Formation and Governance. \\ Journal of Investment and Management. Vol. 7, No. 5, 2018, pp. 133-142. doi: 10.11648/j.jim.20180705.11
}

Received: October 10, 2018; Accepted: October 31, 2018; Published: November 19, 2018

\begin{abstract}
Public-Private Partnerships (PPPs), as an important mean to establish a standardized local government debt financing mechanism, relieve the pressure of local government debt, resolve the fund shortage of urbanization and promote supply-side structural reform, has increasingly become the main mode and source of China's infrastructure investment and financing. It has made an important contribution to the increase of supply scale, quality and efficiency in public services and infrastructures. But with the rapid promotion and widespread, local government provided illegal guarantees of fixed income and repurchase, or beared the loss of principal, issued Local Government Financing Vehicles(LGFVs) debts, and even disguised government purchasing services, which have make the PPPs alienated into a new financing vehicles. This paper defines the concept and scope of local government implicit debt, analyzes the tool characteristics of PPPs, the necessary and sufficient conditions for debt governance function of PPPs, and the formation mechanism, manifestation and evolution path of local government implicit debt. Then several countermeasures of implicit debt governance and risk prevention strategies under PPPs are put forward, including clarifying the relationship between the government and the market, promoting PPPs debt governance through win-win cooperation, improving PPPs laws and regulations, strengthening PPPs performance management, and improving PPPs risk sharing mechanism.
\end{abstract}

Keywords: PPPs, Local Government, Implicit Debt, Formation, Governance

\section{Introduction}

Compared with the explicit debt of local government, the implicit debt is large in scale, low in transparency, diversified in debtors and debt forms, and unsustainable sources of repayment It has become one of the main sources of fiscal risk in China. Since 2017, the PPPs have entered the normative development stage, the LGFVs have basically transformed, and most of the stock explicit debt has been converted into local government bonds through bond replacement. The scale of explicit debt is measurable and the use basically conforms to the "golden rule", the risk is generally controllable [1]. According to the "www.mof.gov.cn" and China Economy Information Net (CEINET), local government debt balance in China was 16.47 trillion yuan in 2017, and the ratio of debt to GDP was $36.2 \%$, which was lower than EU warning line $(60 \%)$; the ratio of debt to disposable fiscal revenue is $80.5 \%$, which is under the international warning line(100\%-120\%).

However, local governments guaranteed various loans and debts through LGFVs, shadow banking and other channels, have formed a large number of implicit debts before the implementation of the new Budget Law in 2014 [2]. After 2015, some local governments formed new types of implicit debts through PPPs commitment to fixed income or repurchase, raising debts in the name of shares, disguising government purchases of services, issuing LGFVs debts and so on [3]. These debts were outside the scope of policy supervision. Fitch Ratings has downgraded China's local currency credit rating to $\mathrm{A}+$ level on the grounds that it is worried about the expansion of China's local government debt and shadow banking. Subsequently, Moody's downgraded China's rating outlook from "positive" to "stable" on the grounds that contingent liabilities may affect the balance sheet quality. The problem of local government implicit debt and its hidden risk has aroused high concern from Policy makers and regulators, as well as scholars. Relevant departments have introduced measures to curb implicit debt risks, and local governments at all levels are trying nervously to find out the 
real implicit debt situation, identify and defuse risks too.

Public-Private Partnerships, as an important mean to establish a standardized local government debt financing mechanism, relieve the pressure of local government debt, resolve the fund shortage of urbanization and promote China's supply-side structural reform [4], has increasingly become the main mode and source of China's infrastructure investment and financing. It has made an important contribution to the increase of supply scale, quality and efficiency in public services and infrastructures. However, according to the "www.mof.gov.cn", Vice Minister of Finance Shi Yaobin posted his views that there are four major problems such as the "solidification" of expenditure responsibility, the "virtualization" of expenditure ceiling, the "dilution" of operation content and the "generalization" of application scope in the development of PPPs. with the rapid promotion and widespread of PPPs across the country, government implicit debt has become more diversified, which may have a big impact on local finances and local economies [5].

Based on review of the existing literatures, interpretation of laws, regulations and policies, as well as investigations and expert interviews, this paper analyzes the concept, scope and formation mechanism of local government implicit debt under PPPs, and then proposes the governance path.

\section{Local Government Implicit Debt}

\subsection{Concept and Scope}

Implicit debt, also known as "invisible debt" or "potential debt", is the debt in a literal sense that has not yet been shown or predicted inside the financial statements. In reality, it mainly includes implicit guaranteed debt, contingent debt, illegal and irregular financing debt, etc.

Different subject areas have different definitions of implicit debt. In the legal sense, more emphasis is placed on the nature of debt and the legal basis for handling debt disputes, which must be defined by strict national laws and regulations. After the implementation of the new Budget Law in 2015, China's local government only have one way to form debt, that is to issue bonds. So implicit debt is not a government debt in the legal sense. In the accounting sense, "Government Accounting Standards - Basic Standards" (Ministry of Finance Order No.78) and "Financial Budget Accounting System" (Ministry of Finance [2015] No.192) both consider government debt to be the government's actual obligation to assume responsibility for expenditure in current conditions, not include contingent and implicit debt. In the economic sense, the government, as the undertaker and manager of public risks, will inevitably lead to the outflow of public resources in the process of preventing the resolution of major public risks. Such outflows may be current expenditure obligation, or may be future and potential expenditure obligation. If it's the former, it will form a direct government explicit debt. If it's the latter, it is reflected as the government's implicit debt. The implicit debt can be divided into direct implicit debt and contingent implicit debt according to the certainty of debt liability. For example, when state-owned enterprises and institutions face debt repayment crisis on behalf of the government to perform supply duties of public goods and services, or when private risks may turn into public risks, the government must bear these as "legal" debts, which belong to the government contingent implicit debt.

From an academic point of view, the recognition of government debt is relatively broad. Any debts that the government is or may be responsible for repay or expenditure are considered to be government debts. The implicit debt comes from the government's commitment to support the future and is essentially a government debt. Therefore, the scope of government debt should be extended from direct debt to implicit debt [6]. There are a large number of government contingent implicit debts in infrastructure construction, which have become an important factor of threatening fiscal stability [7]. Dooly refers to the difference between the government's debt stock and the accumulated deficit as "the big mouth of the crocodile", and believes that this difference reflects the scale of the government implicit debt to a certain extent. The fiscal risk matrix can divide government debt into explicit debt and implicit debt from the perspective of legal liability and moral responsibility. Explicit debt is the debt recognized by law or contract; implicit debt refers to the government's moral responsibility, public expectations, or interest group pressure [8].

From the perspective of government debt management, according to the newly released series of policy documents, local government implicit debt mainly refers to government expenditures and contingent expenditure obligations formed by local government through illegal or disguised debts.

To sum up, the current definition of local government implicit debt in China has not yet been unified and brought troubles to the statistical analysis. We divides the local government implicit debt into three Classes. Class I is government implicit debt in the academic sense, Class II is government implicit debt on the perspective of government debt management, and Class IV is government implicit debt understood by the media and the public. The details are as follows:

Table 1. The scope and classification of local government debt and implicit debt in China.

\begin{tabular}{|c|c|c|c|c|c|c|}
\hline $\begin{array}{l}\text { Statistical } \\
\text { caliber }\end{array}$ & Debt type & Debt scope & Nature & \multicolumn{3}{|c|}{ Classification } \\
\hline \multirow{2}{*}{$\begin{array}{l}\text { Debt } \\
\text { within the } \\
\text { scope of } \\
\text { the audit }\end{array}$} & $\begin{array}{l}\text { Responsible } \\
\text { debt }\end{array}$ & $\begin{array}{l}\text { Treasury bonds to loan funds; Local government bonds; debts } \\
\text { borrowed or defaulted by local government departments, } \\
\text { institutions and LGFVs, which repaid determinately by financial }\end{array}$ & $\begin{array}{l}\text { Direct } \\
\text { explicit debt }\end{array}$ & \multirow{2}{*}{$\begin{array}{l}\text { Explicit } \\
\text { debt in } \\
\text { academic } \\
\text { and legal } \\
\text { sense }\end{array}$} & \multicolumn{2}{|c|}{$\begin{array}{l}\text { Government debt in } \\
\text { accounting sense }\end{array}$} \\
\hline & $\begin{array}{l}\text { Guaranteed } \\
\text { debt }\end{array}$ & $\begin{array}{l}\text { Guaranteed by the government, the government shall bear the } \\
\text { debts jointly and severally liable to the guarantor (debtor) in } \\
\text { case of difficulties in repayment. }\end{array}$ & $\begin{array}{l}\text { Contingent } \\
\text { explicit debt }\end{array}$ & & $\begin{array}{l}\text { II class: } \\
\text { implicit debt in } \\
\text { management }\end{array}$ & $\begin{array}{l}\text { IV class: } \\
\text { implicit debt } \\
\text { understood }\end{array}$ \\
\hline
\end{tabular}




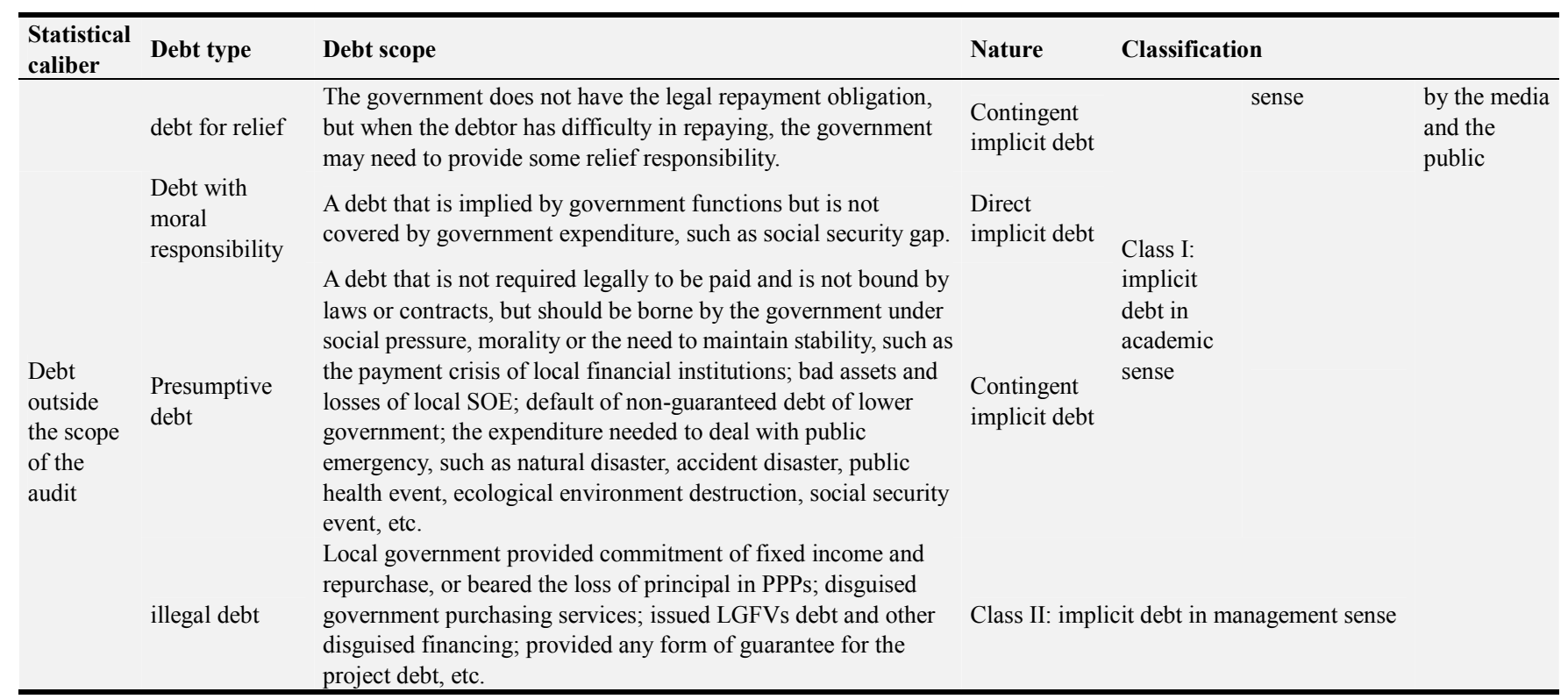

Source: Authors' inductive analysis.

\subsection{Research Review}

According to the existing literatures, the formation of government implicit debt under PPPs is mainly analyzed from three aspects: the motivation of government to carry out PPP projects, the deviation of cost-benefit estimation of PPP projects, and the consequence of risk guarantee provided by the government. The early PPP financing scheme was mainly aimed at evading fiscal expenditure control [9]. Private capital participation in the PPPs is simply a way for governments to finance infrastructure through implicit (or hidden) budget deficit and debt [10]. Costs are usually underestimated and benefits are usually overestimated in public infrastructure projects, and more than $50 \%$ of the estimated error is a common phenomenon rather than an exception [11]. Argentina, Brazil and Mexico also had the problem of underestimated cost and overestimated net income in PPP highway construction projects, which leading to excessive risk guarantee by the government [12]. Took the government risk guarantee in the PPP project of Russian railway construction as an example, the guarantee cost was an important factor causing the financial crisis [13]. The government guarantee for PPP projects further aggravate local fiscal risks, which might become a part of implicit liabilities in government balance sheet. In the absence of appropriate regulatory mechanisms, government guarantee is likely to be overused, such as over-commitment leading to increased debt risk and leaving more debt for their successors [14]. The "false PPP" project clearly as "the lack of project identification procedures, the virtualization in cooperation and risk sharing mechanism, the fixed return or repurchase to expand government responsibility, and the debt raising in the form of shares to evade government responsibility" [15]. There are three aspects to against false PPPs from by defining clearly about the qualification of PPPs' implementation subject, the project investment field, the project operation procedure and deadline.

Although the government risk guarantee has a series of consequences, it is widely used in various forms all over the world. For example, the Spanish government made it clear in the relevant law of toll road franchise in 1972 that the government would provide risk guarantee for $75 \%$ of foreign loans and bear all exchange rate risk [16]. The south Korean government provides risk guarantee for the construction side of PPP project to forecast a certain proportion of income [17] The Indian government provides a 5\% guarantee for the social capital involved in railway construction. The French government offers a yield guarantee of $4.65 \%$ for new rail networks.

Since the 21 st century, with theoretical research as the guide, there has been an increasing number of empirical studies on government implicit debt, including the incidence and determinants of government implicit guarantee on Banks [18] and evaluation of economic distortion effect [19], the implicit debt burden ratio of the social security system [20], the impact of implicit contingent liabilities formed by natural disasters on economic society and debt-paying ability [21], etc. But there are few relevant researches on the formation mechanism, manifestation and evolution trend of the local government's implicit debt risk under PPPs theoretically, so it is impossible to put forward the governance countermeasures of local government implicit debt with important practical reference value to the government regulatory authorities.

\section{The Formation Mechanism of Local Government Implicit Debt in PPPs}

Government debt is a positive form of fiscal policy in Keynesian theory. In fact, the formation of local government implicit debt has its inevitability, and corresponds to specific historical conditions, the institutional environment and the 
economy situation. So we should treat it dialectically, explore the real formation process and roots, and analyzes the evolution trend of the future, then restricte it within a reasonable and legal orbit range. Combined with existing research [22], China's implicit debt Generated logic can be summarized as follows:

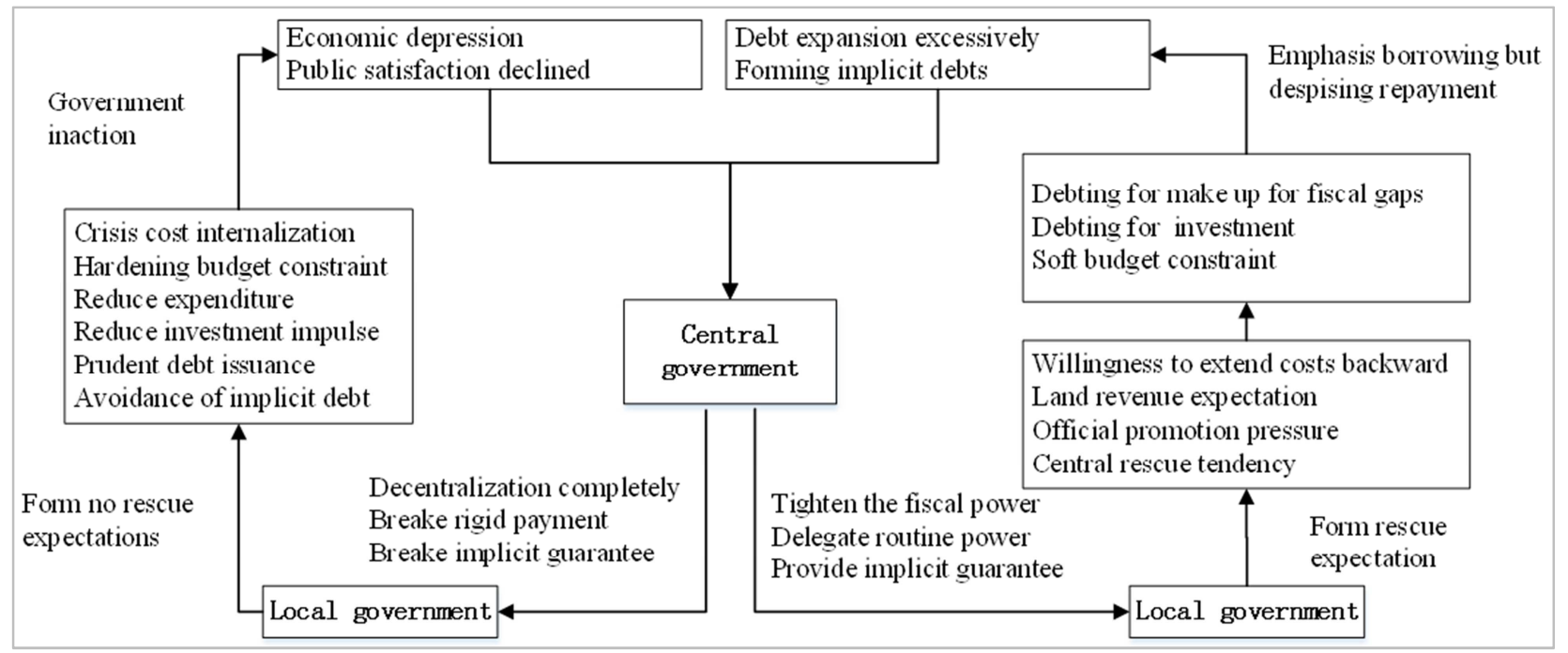

Figure 1. Fiscal decentralization, implicit guarantee and implicit debt generation logic of China s local government.

The formation of local government implicit debt under PPPs is not only related to China's special political and economic system, investment and financing system, but also closely related to the instrumental characteristics of PPPs itself. The unmatching of administrative authority and expenditure responsibility and the imperfect financing system are the institutional root of the formation of implicit debt. However, since it is impossible for mechanism to achieve dramatic transformation or produce significant reform result in a short term, this paper only takes it as a conditional constraint variable. We focuse on the formation mechanism of implicit debt under PPPs, based on the characteristics of PPP tools, financing mechanism, return and risk sharing mechanism, governments' behavior motivation, and LGFVs transformation. Then we put forward the idea of preventing and resolving implicit debt.

\subsection{Instrumental Characteristics of the PPP Model}

PPPs is a compound tool of investment and financing with the following characteristics. First, it can promote the inter-temporal match of investment and income. Infrastructure construction has the characteristics of large investment scale, long term, wide beneficiary groups and long benefit period. This determines that it is difficult for local government to provide construction fund through fiscal revenue in the current year. The cooperation mechanism of "risk sharing and revenue sharing" not only improves the efficiency of project operation, but also matches reasonably the risk of each participating entity. The second characteristic is to conceal government debt. As a new public product financing model, the current government accounting standards can neither record the huge PPPs assets and corresponding expenditure liabilities, nor fully reflect the long-term and periodic characteristics of PPP projects. The liabilities for the expenditure of PPPs are transferred from the table to the off-balance sheet and formed implicit debts. Moreover, PPPs can promote intergenerational equity. Public goods benefit for a long period of time, if the entire investment construction funds are financed by contemporary taxes, it will form the intergenerational injustice of "one generation plants the trees in whose shade another generation rests". PPPs can realize "Who benefits, who governs, who is responsible", which is a more reasonable way of government financing. Fourth, PPPs can leverage more social capital into the supply of public goods and services with a smaller fiscal fund, so that the public will benefit earlier. A large number of microeconomic theories were used to compare the PPPs and the government Own Investment (OI). The IMF builded a dynamic stochastic general equilibrium model on the perspective of macro economic, with conclusion that costs are higher under the PPPs compared with OI, but PPPs can form a higher quality of infrastructure project progress, more reliable, higher social rate of return (average increased by $2 \%-9 \%$ ), and more effectively solve the problem of unemployment and poverty [23].

\subsection{The Necessary and Sufficient Conditions for the Function of Government Debt Management in PPPs}

"State Council's Opinions on Strengthening Local Government Debt Management"(document 43 [2014] proclaimed by State Council) proposed to popularize and use PPPs to accelerate the establishment of a standardized debt financing mechanism for local government. Using PPP tools to manage local government debt is an innovation. However, the function of debt governance of PPP tools needs certain preconditions. First, perfect financial investment system and supervision mechanism to prevent the formation of new implicit debts. The second is to carry out project-based debt screening and performance evaluation based on the reasonable 
sharing of risks [24]. The third is to promote PPPs prudently in views of the stage of development, maturity and real social needs. Avoiding "rush into action blindly" or "go all out and go fast", and fake PPP without substance or income guarantee. Fourth, PPPs' cost and future operating income are difficult to accurate because of it's large investment scales, long operating cycles, and many uncertainties such as exchange rate, policy changes and many other factors. Therefore, it is necessary to ensure that information is opened and transparent to reduce the estimation deviation, and at the same time do a good job in medium and long-term fiscal planning and risk management in whole-of life cycle. The fifth is a team of professionals with certain PPP operational capabilities.

\subsection{Implicit Debt Formation Mechanism Based on PPPs Financing Mechanism}

The tool features of PPPs make it become one of the tools of government debt governance. At the same time, it is possible to form new implicit debt through PPPs. The promotion of PPPs is closely related to the demand of local government debt governance and the formation of implicit debt. In the context of the global financial crisis in 2008, China's four-trillion-yuan fiscal investment stimulus program made local governments borrow large amounts of debt through LGFVs, which have increased the fiscal risk. At the same time, the contradiction between the people's growing need for a better life and the imbalance and inadequate development has become the major social contradiction. It has become an important function of the government to increase the supply of public goods and services to meet the people's diversified demands. As debt rising rapidly and policy regulation tightening, the space for further debt financing by local governments has been very limited. The PPPs has undoubtedly become the best alternative to government debt financing and debt governance. However, if the debt financing scale of PPP projects is excessive, the leverage ratio is too high, or exceeded the level of local economic development, new government implicit debt may be formed. For example, a large number of empirical results abroad show that there is a positive relationship between PPP investment and regional per capita GDP, but China is an exception.

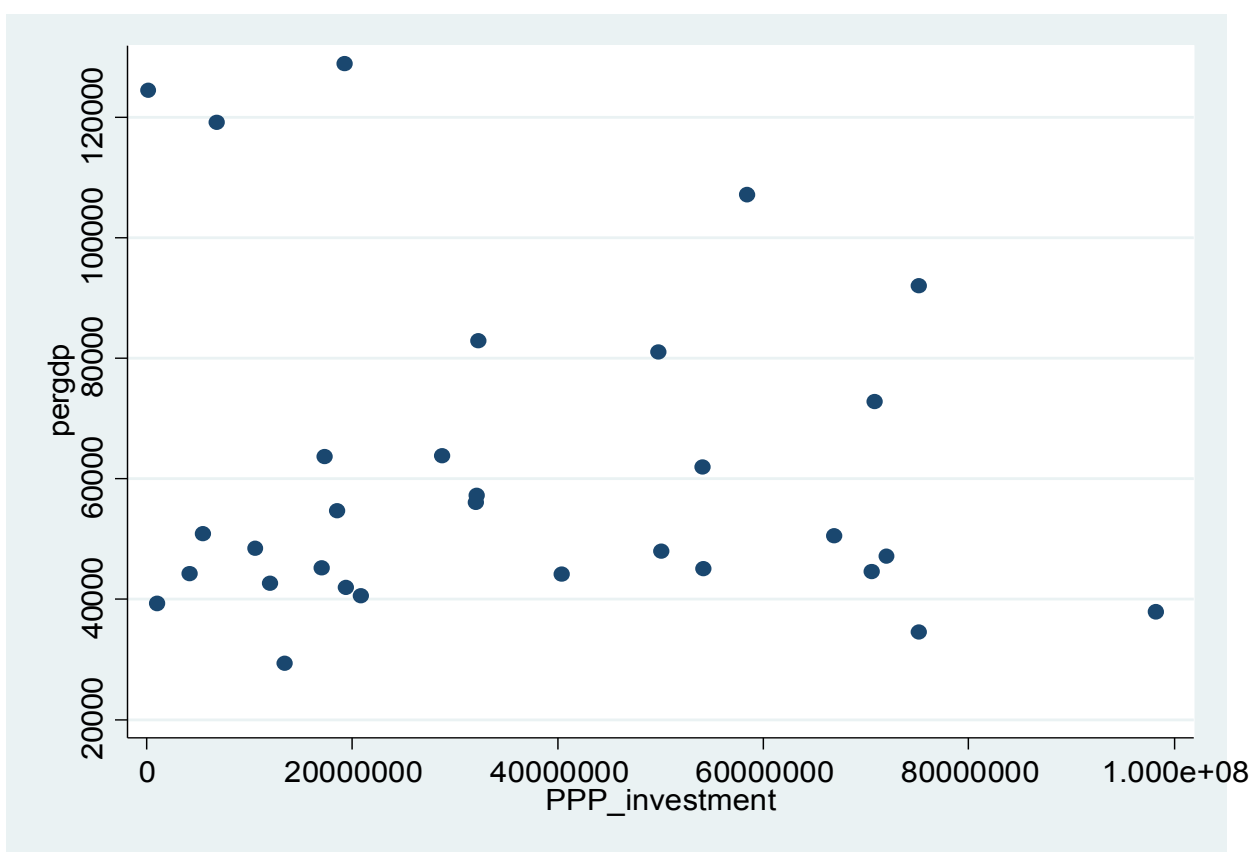

Data Source: From China Public Private Partnerships Center, http://www.cpppc.org/.

Figure 2. A scatter diagram of PPP investment and per capita GDP in provinces and cities of China in 2017.

As shown in Figure 2, the positive relationship between China's PPP investment and per capita GDP in 2017 is not significant, and there is even a certain negative relationship. The provinces and cities with low per capita GDP have high PPP investment, such as Yunnan, Guizhou and Sichuan, while those with high per capita GDP have low PPP investment, such as Shanghai, Beijing and Tianjin. To a certain extent, this indicates that the PPPs mainly undertakes a task of "compensating for shortcomings" and supply-side structural reform in China. Therefore the risk is greater, the quality is generally not so high, and it is easy to form implicit debt risk. On the other hand, the infrastructure construction of poor provinces and cities in China usually hard to attract private investment enough due to low profitability. In fact, many of them are involved by state-owned enterprises as social capital, not private capital substantively, which makes public risk accumulate within the departmental system, and further increase the government's implicit debt risk. Table 2 reveal the mechanism of implicit government debt based on PPP financing mechanism. 
Table 2. Mechanism of implicit government debt based on PPP financing mechanism.

\begin{tabular}{|c|c|c|}
\hline Mechanism & Debt Governance Function & Implicit Debt Formation Mechanism \\
\hline $\begin{array}{l}\text { Social } \\
\text { financing } \\
\text { mechanism }\end{array}$ & $\begin{array}{l}\text { By widely introduced social capital to invest in public goods } \\
\text { and services, the pressure of local government capital } \\
\text { demand and debt growth might be alleviated. }\end{array}$ & $\begin{array}{l}\text { The leverage ratio of the PPPs is usually higher when the social capital parties } \\
\text { raise funds in the form of loan. In fact, this ratio is changed from the previous } \\
\text { government borrowing investment to private sector borrowing investment. } \\
\text { High ratio has not changed fundamentally. Once the project operation fails } \\
\text { and the private sectors responded with default, the bank's non-performing } \\
\text { loans are bound to increase. Systemic financial risk may be triggered too. The } \\
\text { government has to bear the responsibility for the bottom line to prevent and } \\
\text { resolve the public risk, thus forming the implicit government debt. }\end{array}$ \\
\hline $\begin{array}{l}\text { Market } \\
\text { selection } \\
\text { mechanism }\end{array}$ & $\begin{array}{l}\text { When introduce social capital, the one with qualifications, } \\
\text { strength and relevant experience of project construction and } \\
\text { operation are selected by competitive bidding and tendering, } \\
\text { which can effectively guarantee the project implementation; } \\
\text { In the construction and operation phase, the private sector's } \\
\text { management experience, technology and capital advantages } \\
\text { can improve the efficiency of debt capital use. }\end{array}$ & $\begin{array}{l}\text { If the check of introducing is not strict and the operation is not standard, the } \\
\text { fake PPP projects will be formed and the government implicit debt risk will be } \\
\text { increased. If the social capital side pursues too much profit maximization } \\
\text { might lead to goal differentiates with government. Once the social capital side } \\
\text { fails to achieve the established goal, it will cause default, bankruptcy which } \\
\text { may form the implicit government debt, etc. }\end{array}$ \\
\hline
\end{tabular}

Source: Authors' inductive analysis.

\subsection{Implicit Debt Formation Mechanism Based on PPPs Return Mechanism}

With the vigorous promotion of PPPs, there are 7,137 projects inside the PPP comprehensive information platform management library across the country with an investment of 11 trillion yuan by the end of 2017 , of which $8.4 \%$ were User-fee PPPs, $62.7 \%$ were Viability gap funding for PPPs , and $28.9 \%$ were availability-based PPPs.

Table 3. Investment in PPP project under different return mechanism in China Unit: RMB 10,000

\begin{tabular}{|c|c|c|c|c|}
\hline year & User-fee PPPs & Viability Gap Funding for PPPs & Availability-based PPPs & Summation \\
\hline 2010 & 262,440 & $1,847,570$ & 0 & $2,110,010$ \\
\hline 2011 & $2,615,800$ & $1,026,084$ & 0 & $3,641,884$ \\
\hline 2012 & $3,440,492$ & $7,632,418$ & 124,387 & $11,197,297$ \\
\hline 2013 & $1,511,022$ & $7,567,026$ & $1,149,061$ & $10,227,109$ \\
\hline 2014 & $8,999,281$ & $32,849,083$ & $9,709,095$ & $51,557,459$ \\
\hline 2015 & $32,419,047$ & $185,000,563$ & $86,155,025$ & $303,574,635$ \\
\hline 2016 & $23,147,779$ & $229,979,239$ & $112,432,366$ & $365,559,384$ \\
\hline 2017 & $21,912,272$ & $240,526,440$ & $116,526,921$ & $378,965,633$ \\
\hline Total & $94,308,133$ & $706,428,423$ & $326,096,855$ & $1,126,833,411$ \\
\hline proportion & $8.4 \%$ & $62.7 \%$ & $28.9 \%$ & $100.0 \%$ \\
\hline
\end{tabular}

Data source: From China Public Private Partnerships Center, http://www.cpppc.org/ .

From the perspective of PPP project return mechanism, availability-based PPPs may face the risk of government credit default, "new government officials ignoring old accounts", policy changes, insufficient financial capacity, and so on. User-fee PPPs may face insufficient demand, difficult to select the charging mechanism, and difficult to carry out exclusive mechanism. Viability gap funding for PPPs may exist probloms that participants package false PPP projects in order to obtain more financial subsidies. These risk factors make it difficult to predict the income, expenditure, cash flow and profitability of PPP projects in the next 10-30 years, and the enthusiasm of social capitalists is not high. In order to attract the participation of social capital, local governments have committed to buy back equity financing at maturity, or promised a reasonable level of return, thus forming government implicit debt .

\subsection{Implicit Debt Formation Mechanism Based on the Local Governments' Behavior Motivation}

The policy tools of supporting PPPs development by local government include general budget expenditure, government investment fund participation, land allocation, construction subsidy, operation subsidy, supporting input, government payment (availability payment and operation subsidy) and other policy supports. In the process of using these policy tools to support PPP development, local governments may form implicit debt in the following ways: 1) Relying on PPPs to expand government financing scale by means of funds, capital management plan, financial leasing and trust to avoid fiscal budget constraint. With the fiscal expenditure responsibility of PPPs reaching $10 \%$ of general public budget expenditure, some local governments support PPP projects by means of governmental fund expenditure to avoid this policy 
red line. 2) In order to obtain more financial incentives, preferential policies and feasible subsidies for PPPs, local governments usually have strong motivation to promote PPPs, even packaging "fake PPP" projects jointly with enterprises. 3) Local governments often underestimate costs and overestimate the revenues in a certain "wishful wish" way in order to maximize the provision of public goods and public services [25], which make the cost overrun and the revenue lower than expected in the actual construction and operation stage. It is very common and accelerates the government's implicit debt risk. For example, long-term loss-making operations such as Hechi Airport in Guangxi Zhuang Autonomous Region, Yuncheng Airport in Shanxi Province, and Changshui Airport in Yunnan Province are caused by local government's distorted GDP performance and inadequate cost-benefit estimation, especially the estimation of traffic passenger. According to the national development plan, more than 500 general airports will be built by 2020 , with a total investment of more than 1 trillion yuan. In the name of emphasizing social benefits, ignoring economic effects and operational capability, this overbuilding behavior will eventually lead to a large number of implicit government debts, and affect financial sustainability and local stable development. 4) Under the PPPs, the government provides SPV company with various forms of guarantees, such as cost overrun risk guarantee, insufficient income risk guarantee, capital rate of return risk guarantee, total yield risk guarantee and so on, thus forming government implicit debt. Take the PPP urban rail transit project as an example, suppose the government provides SPV with a preliminary design and agrees to compensate for the cost increase caused by the design change or certain unpredictable specific events. If the government adjusts the design route from light rail to subway for the purpose of the social public's political pressure or protecting humanistic and ecological landscape, the extra cost of SPV company and expected income decrease caused by the change may be compensated by the government. Furthermore, the government may be required to compensate SPV for the delay and cost of the project, assuming that environmental governance is required in the proposed area. In addition, the future exchange rate changes, future steel price rise and other factors may also require the government to bear some compensation liability. It can be seen that the PPPs actually implies a certain government expenditure responsibility in the future, which is essentially the implicit debt of the government.

In addition, factors such as corruption, information asymmetry, excessive government control, uncontrollable medium and long-term budget, limited accounting system, and inadequate information disclosure mechanism may also lead to the failure of PPPs. The failure of PPPs usually form government implicit debt as PPPs aiming at providing public and quasi-public goods. The "fake PPP" projects that violate regulations will trap the public finance, trigger a PPP bubble, and then form local government implicit debts.

\subsection{Implicit Debt Formation Mechanism Based on Participating PPPs of LGFVs After Transformation}

Local Government Financing Vehicles (LGFVs) are entities set up by local governments to finance primarily for infrastructure construction. Due to the incomplete transformation of LGFVs, their participation in PPPs has increased the risk of project operation. In the process of standardizing the liquidation of debts, the LGFVs bear the main responsibility, but the existing policies require them to withdraw from the government financing field. LGFVs had to "open up another way", such as participating in PPP in forms of "stock nominally but debt substantially". However, LGFVs themselves have already been heavily indebted before they quit the government financing field, and were prohibited to finance rely on government credit by policies and regulations, the participating in PPPs as social capital parties with huge debt burden might increase the risk of PPP projects. Although the external liabilities of LGFVs and the participation as investors in PPPs are not the same thing, it is undeniable that the success or failure of PPPs depends largely on the strength of social capital parties and their ability to cope with risk. Once the PPPs fails, it should be handled in accordance with the principle of risk sharing. However, if the LGFVs as social capital parties do not have the ability to share risk, it might increase the government's burden, force the government to take on all debts, and even trigger a systemic financial crisis. Moreover, the LGFVs with incompletely transformation are still inextricably linked with the government, while LGFVs which transformed completely into local state-owned enterprises may formed a government implicit debt for rescue responsibility in the case of enterprise loss or high debt. In addition, the local financial guarantee for LGFVs's financing and the central government's implicit guarantee for local governments make vehicle risk to be easily transformed into financial risk and central government's debt risk. This could easily trigger a systemic debt crisis that would hurt national and global growth. Therefore, in this sense, the debt risk of LGFVs is one of the most important sources of local government implicit debt.

\section{The Governance Path of Implicit Government Debt in PPPs}

Policymakers have explored the ideas and Countermeasures of local government debt governance from the aspects of fiscal system, financial system and political system, such as government bond issuance, debt replacement, LGFVs transformation, new capital management regulations, administrative accountability and so on. In fact, LGFVs, PPPs, government investment funds, government special bonds and so on may become vehicles for government borrowing in disguise. The standardized management of PPPs is not just a matter of simply quiting the PPP project library, but to negotiate and rectify. To clarify the relationship between the government and the market from the system, to draw a clear 
line between the government debt and company debt of the PPPs from the practice, and then to grasp the formation mechanism and evolution path of the implicit debt under PPPs is the prerequisite. Specific measures such as rationalize the risk sharing mechanism, improving the PPP laws and regulations, strengthening the integration of construction and operation as well as the project performance management, scientific repurchase methods and preferential development of user-fee PPPs should be taken up to prevent new implicit debts and avoid PPPs alienation as a new government financing vehicle.

\subsection{Clarify the Relationship Between the Government and the Market}

Managing the relationship between government and market has always been the core of China's economic reform. The reason why the market plays a "decisive" role in resource allocation is that the Chinese market is not fully developed and the boundary between the government and the market is blurred. There are many problems such as government involving in too many competitive projects, excessive intervention and inadequate supervision and so on. In the fields of supply of public goods and services, the PPPs has be adopted widely in developed countries, while China just only started to promote it vigorously in recent years. Although the development speed is relatively fast, the participation rate of social capital is low, and problems such as raising debts in the name of shares and "fake PPP" are prominent. Under the promotion incentive mechanism of officials, some local governments have strong investment impulses, which can easily lead to crowding out effect of private investment, inhibit the vitality of social capital, increase the pressure of government funds and restrict the efficient allocation of resources. Therefore, it is necessary to clarify the relationship between the government and the market, position the government function well, promote social capital to participate in the supply of public goods and services, and avoid the local government to do all the work.

\subsection{Change Mindset and Promote PPP Debt Governance Through Win-win Cooperation}

In the past, local governments generally regarded the PPPs as a new ways of government financing, so more PPP projects were promoted from the perspective of the government's own needs and interests. This is actually not conducive to achieving win-win cooperation with social capital. The government's function positioning in PPP operation can be referred to the discussion of "market platform view" in new market finance, that is, "the market is regarded as a trading platform, and the state is the regulation of market political boundary; the government is a participant in the market, a member of the social economy and a 'trustee' of the state, whose behavior is regulated by the state. The private sector trades to maximize private value while the public sector carries out market activities to maximize its public value" [26]. The government should change its traditional concept, abandon the high bureaucratic style and lower its posture, orientate its own functions scientifically. Most importantly, elevating the PPPs to the height of social governance and debt governance, participating in the promotion, construction and operation of PPP projects as one of the equal participants in the market is necessary for harmony co-governance with the social capital side. These enables all kinds of resources to be rationally allocated and efficiently used, and enables people to make the best use of their talents, materials and finances.

\subsection{Improve PPPs Laws and Regulations to Promoted the Transition From "Rule by Man" to "Rule by Law"}

The PPPs in China is still in its start stage. Although the government has issued a series of policy documents to regulate the development, but the lack of institutional regulations at the legal level make the efficiency level not so high. The legal system in the field of PPPs should be established as soon as possible. The relatonships of rights, responsibilities, obligations and risk sharing mechanisms in PPPs should be clearly defined so as to enhance the participants' consciousness of responsibility, rights and risk. Only in this way can we create an efficient and targeted behavior restraints and incentives, improve social capital's confidence, participation enthusiasm and project landing rate, as well as avoid the "power rent-seeking" and government "pass the buck" and social injustice.

\subsection{Strengthening the PPPs Performance Management}

The performance management of PPP projects should be strengthened by standardizing the behavior of project participants, improving the participation enthusiasm of social capital, and arranging fiscal expenditure reasonably.

First of all, the top-level design of PPPs performance evaluation should be done well. China has not yet developed systematic performance evaluation specifications specifically for the whole-of life cycle of PPPs. The principle, target, object, evaluation standard, implementation subject, specific indicator system, supervision management and application of evaluation result should be formulated as soon as possible.

Secondly, it's necessary to build a result-oriented project performance evaluation system, with performance standards of materialization, refinement and quantification. A perfect performance management system of PPPs should include the process of design, evaluation, tracking and application. The government, social capital and project company should be taken as the evaluation subjects separately. The financial funds performance, social capital operation performance and project management performance should be adopted as the evaluation contents separately. Due to the differences in interest demands, goal oriented, responsibilities among participants, the performance evaluation should be guided by the results. The PPPs budget expenditure should incorporate into the framework of fiscal expenditure performance evaluation in project; the performance evaluation of social capital operation should incorporate into marketization management framework; and the performance evaluation of 
project should incorporate into the management framework of whole-of life cycle of PPP projects.

Thirdly, deepen the management of the PPP project library. It's necessary to review the value for money evaluation and the financial affordability evaluation strictly, and exclude those projects which are fake PPP, without substantial operational content, and not suitable for PPP mode. Conduct real-time dynamic monitoring of PPP projects in the library, and timely clean up the delivery of those projects with non-conforming conditions, non-standard operation and incomplete information, so as to avoid the project generalization, alienation and solidification as the responsibility of government expenditure.

Finally, strengthen the spirit of contractual cooperation among local governments and improve the accountability mechanism. Link the project implementation rate and scheduled situation, risk supervision to the performance of main person in charge and related leaders of local governments, and ensure that there will be no large-scale default, false packaging and breach of regulatory review requirements of PPP projects during their term of office. In the off-office auditing of the relevant leading cadres, the key assessment is whether the project implementation schedule is up to standard, whether there is potential risk leading to project failure or debt default, so as to strengthen the accountability mechanism.

\subsection{Improve PPPs Risk Sharing Mechanism}

Scientific, rational and specific risk sharing mechanism is the best guarantee to guard against implicit debt risk. The PPPs risk sharing mechanism should be design by considering comprehensively the risk type, the risk management ability of each participant, the project return mechanism, the project phase and the industry characteristics.

The principles of PPPs risk sharing includ that the risk is borne by the party who has the optimal control over the risk, the risk is matched with the return, and the risk should have the upper limit [27]. According to these principles, government shouldn't provide risk guarantee for the whole project (such as guarantee for the return on investment) to avoid reducing efficiency and the willingness of the social capital side to control risk.

The risk that social capital is good at managing shouldn't assigne to the government to provide risk guarantee, such as project construction cost risk, deferred delivery risk, construction quality risk, etc. Government risk guarantee should be based on performance.

User-fee PPPs focus on the balance between the public interest and the reasonable return of social capital. On the basis of promoting the advantages of each participant, the government can provide certain guarantee for the risk of insufficient demand, or make a "uniqueness" commitment, or realize risk sharing through equity cooperation.

Availability-based PPPs focus on the balance between performance monitoring continuously and encouraging operators to improve efficiency, and implement the responsibility of payment according to performance and supply of relevant supporting facilities strictly.

Define the risk sharing methods in the PPPs contract, such as paying liquidated damages, extending the cooperation period, expanding the franchise, reducing the franchise fee, increasing the performance guarantee and making reasonable compensation etc.

\section{Conclusion}

The PPPs has the function of debt governance, but itself can also form new types of government implicit debts by irregularities and poor management. The new types of implicit debts include the commitment to fixed income or repurchase, raising debts in the name of shares, disguising government purchases of services, issuing LGFVs debts and so on. At the same time, the failure of PPP projects may also lead to government implicit debts since most of PPP projects are public or quasi-public goods projects, which cannot be ignored by local governments. Therefore, to ensure the smooth operation of PPPs by improving laws and regulations, strengthening the PPPs' performance management, setting up a scientific and reasonable risk-sharing mechanism are the fundamental ways to avoid the formation of implicit debts.

\section{List of Abbreviations}

PPPs-Public Private Partnerships, LGFVs-Local Government Financing Vehicles, CEINET-China Economy Information Net, OI-Own Investment.

\section{Availability of Data and Material}

All necessary data are within the manuscript.

\section{Acknowledgements}

This paper is financially supported by "Joint project between ministry of finance and central university of finance and economics", entitled "Research on social public assets in China" (Grant number: 201714).

\section{References}

[1] Li Yang, Chang Xin, Yin Jianfeng, Head of the Research Group of the National Finance and Development Laboratory. (2017). China's debt risk is under control. Social Science Daily,(02), $1-3$.

[2] Liu Shangxi. (2015), The rule of law of local government debt. China Finance, (01), 44-49.

[3] Ji Fuxing. (2018) . Governance of local government implicit debt and standardization of investment and financing. Bankers, (03), 98-100.

[4] Yu fengbo, opportunities. (2015). Challenges and countermeasures of PPP mode in the new normal. Financial Forum, (08), 75-80. 
[5] Yu Shuyi. (2016). Guard against new implicit debt drilling system loopholes. China Economic Weekly, (28), 80-82.

[6] Harvey S. Rosen. (2002). Public Finance. China Renmin University Press, 412-428.

[7] Miguel Almeyda, Aergio Hinojosa. (2001). Revision of State of the art contingent Liability Management. The World Bank Policy Research Working Paper.

[8] Hana Polackova Brixi and Allen Schick. (2002). Government at risk: Contingent liabilities and fiscal risk. World Bank, Oxford University Press, 1-16.

[9] Spackman, M. (2002). PPPs: Lessons from the British Approach, Economic Systems, (26), 283-301.

[10] Efraim Sadka. (2007). Public-Private Partnerships-A Public Economics Perspective, CESifo Economic Studies, 53(3), 466490.

[11] Prud'homme, R. (2004), Infrastructure and Development, paper prepared for the Annual World Bank Conference on Development Economics, Washington, DC.

[12] Strong, J. S., J.-L. Guasch and J. Benavides (2004), Managing Risk of Infrastructural Investment in Latin America: Lessons, Issues, and Prescriptions, IDB Working Paper Inter-American Development Bank, Washington.

[13] Westwood. J. N. A (1996). History of Russian Railways. London: George Allen \&Unwin.

[14] Yu Qin. (2016) . China's Transport Infrastructure Investment: Past, Present, and Future, Asian Economic Policy Review, (11), 199-217.

[15] Zhou Lei. (2017). some thoughts on false PPP projects. Property Rights Guide, (10), 45-48.

[16] JA Gómez-Ibáñez, JR Meyer. (1993). Going Private: The International Experience with Transport Privatization. Washington, DC: The Brookings Institution, (2), 132-343.

[17] Helm, Dieter. (2004). Energy, the State, and the Market: British Energy Policy since 1979. Rev. ed. Oxford, U. K.: Oxford University Press.
[18] Sebastian Schich and Sofia Lindh. (2012). Implicit Guarantees for Bank Debt: Where Do We Stand?. OECD Journal: Financial Market Trends, (1).

[19] Sebastian Schich and Yesim Aydin. (2014). Measurement and analysis of implicit guarantees for bank debt: OECD survey results. OECD Journal: Financial Market Trends, (1).

[20] Péter Benczúr. (1999). Changes in the Implicit Debt Burden of the Hungarian Social Security System. NBH Working Papers, (2).

[21] Ian Koetsier. (2017). Natural disasters and implicit government debt. 43(2).

[22] Guo Yuqing, He Yang and Li Dong. (2016). Rescue expectations, public incentives and great power governance of local government debt financing. Economic research, (03), $81-95$.

[23] Edward F. Buffie, Michele Andreolli, Bin Grace Li, and Luis-Felipe Zanna. (2016). Macroeconomic Dimensions of Public-Private Partnerships. IMF Working Paper, (3).

[24] Policy Research Laboratory, Ministry of Finance. (2015). Governance of Local Government Debt from the Perspective of Three Characteristics of PPP. Budget Management and Accounting, (05), 34-35.

[25] Efraim Sadka. (2007). Public-Private Partnerships-A Public Economics Perspective. CESifo Economic Studies, (53) 3, 466-490.

[26] Li Junsheng and Yao Dongzhang. (2018). Reconstructing the Relationship between Government and Market: National View, Government View and Theoretical Origin of New Market Finance. Finance Research, (1), 20-32.

[27] Ke yongjian, wang shouqing and Chen bingquan. (2008). Risk Sharing of PPP Projects in Infrastructure. construction economics, (4), 31-35. 